\title{
Impact of Crude-Oil Spillage Pollution and Chemical Remediation on Agricultural Soil Properties and Crop Growth
}

\author{
${ }^{*}$ ESSIEN, O E; ${ }^{2}$ JOHN, I A
}

Department of Agricultural and Food Engineering, University of Uyo,

P. O. Box 4309, Uniuyo Post Office, Uyo, AKS, Nigeria

\begin{abstract}
Loamy sand of agricultural land in an oil producing and processing area was polluted with crude oil and the fouled soil samples were reclaimed using chemical degreasers and detergents. Both treatments showed significant effect on soil properties and crop growth parameters; however recovery level was 67-100\% and significantly $(\mathrm{p} \leq 0.01)$ higher than the level of degradation, except in infiltration rate. Soil $\mathrm{pH}$ increased by $26 \%$ in fouled soil attributable to bacterial biodegradation of crude oil under the anaerobic conditions present in the soil macro and micro-pores, and indicated the tendency of crude oil spills to buffer acidic soil to neutral. Hydraulic conductivity with $45-67 \%$ reduction from $82.24 \mathrm{~cm} /$ day in the control soil to $39.6 \mathrm{~cm} /$ day in polluted soil confirmed the blockage of polluted soils micropores by oil films. Crop growth, indicated by root elongation, diminished to $7.4 \pm 0.64 \mathrm{~cm}$ in polluted soil compared to $13.47 \pm 6.40 \mathrm{~cm}$ in the control soil. Evapotranspiration and leaf mass water decreased by $90 \%$ while fertility indicated $33-103 \%$ increase in total nitrogen, organic carbon and available phosphorus in the polluted soil. The chemical degreaser/detergent emulsion effectively recovered soil properties and plant growth in the reclaimed soil and is recommended for short-duration restoration of crude-oildegraded soil for productive agriculture. @JASEM
\end{abstract}

Plants germinate, develop and grow in soil medium where water, air and nutrient resources supply plants for healthy growth for productive and profitable agriculture. Frequent crude-oil spillage on agricultural soils, and the consequent fouling effect on all forms of life, render the soil (especially the biologically active surface layer) toxic and unproductive. The oil reduces the soil's fertility such that most of the essential nutrients are no longer available for plant and crop utilization (Abii and Nwosu, 2009). The enormity of toxicity by oil spillage on crop performance is exemplified in mangrove vegetation, which has been dying off in recent times (Henry and Heinke, 2005). Spilled crude-oil which is denser than water, reduces and restricts permeability: organic hydrocarbons which fill the soil pores expel water and air, thus depriving the plant roots the much needed water and air (Brian, 1977). Soil properties involved in soil-plant-water relationship are degradable and include texture, infiltration, hydraulic conductivity, moisture content, $\mathrm{pH}$ and density, which affect root and leaf development and plant growth and yield (Michael, 1978; CIGR, 1999; Michael and Ojha, 2006). Odugwu and Onianwa (1987) demonstrated the effect of pollution on germination, growth and nutrient uptake using pawpaw, and Amadi et al. (1996) demonstrated chronic effects on soil properties and microflora in a rainforest system. Daniel-Kalio and Braide (2004) showed its effect on cultivated wetland areas of the Niger Delta. Other researchers employed maize, capsicum and lycopersicum and dayflower for observation of pollution effect (Anoliefo and Nwosu, 1994; Daniel-Kalio and Pepple, 2006). However, the present research considers the tributary swamps of the wetlands of shallow inland rivers where local technical skill in controlling pollution is still lacking. In addition, to compare the effects and degree of spilled-oil pollution with the concurrent application of chemical degreaser-detergent for its remediation rather than relying on prolonged natural rehabilitation processes or bioremediation are socio-economically and environmentally sensitive enough to be studied (DeWrachien and Chisci, 1999; Ayotamuno and Kogbara, 2005; Ngobiri et al., 2007). Overall, oil spillage affected crop yield and farm income, and by extension, the social and economic livelihoods of farming communities (Odjuvwuederhie et al., 2006; Chinda and Braide, 2000; Atubi and Onokala, 2000).

Crude-oil spillage has frequented the alluvial soils of the coastal plains of the Qua Iboe river wetlands in Akwa Ibom State, Nigeria and deprived the communities of their socioeconomic livelihood. This, in turn, has fostered hostility towards the oil companies when neither the government nor the oil companies acted quickly to accommodate or alleviate effect of the degradation (Aghalino, 2000). Consequently, remedial action (apart from the occasional financial compensation) should have been undertaken to solve the ecological degradation that created economic distress on their agricultural livelihood. Bioremediation and natural rehabilitation, however, take prolonged period and can isolate the actual people affected by the problem from the solution. Therefore, an approach that better involves the affected people in a quick solution could be the chemical remediation route, whereby they could watch, or even participate, as the restoration process is expected to take a short period.

The hydrocarbons found in crude-oil spillage are large and complex molecules, and persistent in nature and may require a strong reagent to counteract their effects on agricultural soil. When droplets of hydrophobic oil are suspended in water, the very 
polar water molecules which attract each other very strongly, in a very short time squeeze out the nonpolar oil molecules, causing them to coalesce and float to the top. When an emulsifying agent like detergent is added, a suitable emulsion of alkyl benzene results with specific gravity of 0.856 (Whitten et al, 1985); the detergents are usually large chemical of sodium salt like sodium lauryl benzene sulfonate, with a polar head and non-polar tail, and if added to oil-water mixture in the pore and shaken vigorously, will form a fine emulsion, which is safely flushed out into drains or released into the environment (Whitten et al, 1985).

The objectives of this research were to determine: (1) the engineering and physical properties of the oilpolluted soil and their effects on crop performance; (2) how chemical reclamation using degreaser/detergent may restore the fouled soil and crop growth; and (3) to compare the degree of soil degradation by pollution and the soil recovery under chemical remediation.

\section{MATERIALS AND METHOD}

Materials: Loamy sand of the coastal plain wetland of the Qua Iboe River in the Eastern Obolo Local Government Area (LGA) was used for field experiment. This area has oil production and pipelines operations going on by one of the many multinational oil companies. Trial crop used was nursery cowpea (Vigna unguiculata) plant. While the polluted soil was contaminated with crude oil, chemical remediation treatment used a degreaser (chemical) and an ordinary detergent (local Omo® - a powdered detergent) that was prepared according to Whitten et al. (1985).

Study site and experimental design: A fallowed farmland was delineated on the run of an oil pipeline from a Tank Farm at Qua village on the alluvial wetland of Eastern Obolo LGA, Akwa Ibom State, Nigeria. Square portions ( $4 \mathrm{~m} \mathrm{x} 4 \mathrm{~m}$ ) were marked out and cleared of vegetation at three plots within the farmland, and they were left to stabilize for three days before treatment. A $3 \times 3$ randomized block design was overlaid on each block to comprise treatments A, B and C, being the control, the crudeoil polluted area and the reclaimed plot respectively. Plot $\mathrm{C}$ was located at patches where crude-oil did not pollute.

Degreaser and detergent application: A solution of 1 litre of degreaser (sodium lauryl benzene sulfonate, $\mathrm{SO}_{3} \mathrm{Na}$ ) mixed with 1 litre of ordinary detergent (Omo® (an emulsifying agent) was poured on the oilpolluted soil and allowed to sit for 2 hours to enable it to break the oil bonds that blocked the micro and macropores of the soil. This solution saturated the pore spaces that contained viscous hydrocarbons, entrapped air, deposited salt, all of which reduced percolation of water, air and nutrients by closing up the pores and increasing soil sliding resistance initially. This situation reduced root penetration and anchorage leading to crop death. Concentric-ring infiltrometers were placed on the polluted soil and the prepared liquid was poured into the inner ring and annulus spaces for proper infiltration into the polluted soil and to cover the root zone. The root zone depth of typical crops of the area (rice, beans and vegetables) was found to be in the range of 30 to 60 cm (Bhattacharya and Michael, 2003). After adding the detergent emulsion to the crude oil-water mixture in the soil pores and then shaking the mixture vigorously, the true emulsion that was formed was flushed out.

Determination of soil properties: The loamy sand texture was $99 \%$ sand and $1 \%$ silt and clay. Soil samples were taken at the three randomly replicated treatment plots to determine soil moisture content, density, permeability, infiltration rate, hydraulic conductivity and soil fertility. Also determined were bio-climate (evapotranspiration) and water deficiency (suction) in plant. The restorative effect of chemical remediation on soil fertility, and growth parameter's (root elongation) response to available water were analyzed with F-ratio. For moisture content, soil samples held in black polythene bags to prevent evaporation loss were collected with soil auger to the profile depth of $15-20 \mathrm{~cm}$ in the plots. After weighing at the laboratory and drying in the oven at $103^{\mathrm{O}} \mathrm{C}$ for 24 hours, the percentage moisture content was calculated on the basis of dry weight. The same procedure was repeated for samples from the polluted, the control and reclaimed plots separately. Evapotranspiration was determined with an improvised lysimeter in which three containers, A, B, and $\mathrm{C}$, of equal size were filled up to three-quarters of their depths with soil samples and planted with beans. After allowing five days to germinate, equal volumes of water were added into the containers on day six. As the days progressed, evapotranspiration reduced water level, hence the weight of each container was taken daily, and water was added till all their weights became equal. The "top-up" volume of water was the water lost by evapotranspiration.

From the third day into the experiment, growth parameters in the soil and in containers were also measured for 21 consecutive days. Root elongation was determined by carefully uprooting seedlings without breaking the roots, removing the soil clogged to the roots and measuring the lengths of each root. Additionally, the loosened soil was used for moisture content and soil nutrient tests. 
Water mass and water deficit in the plants leaves were obtained by oven-drying the cut leaves of the dislodged seedlings to get the dry weights; then computing the percentage mass of water using Equation 1,

$$
\mathrm{mc}_{\mathrm{f}}=100 \times\left(w_{w f}-w_{d f}\right) / w_{w f} \quad 1
$$

where $\mathrm{mc}_{\mathrm{f}}$ was percentage water content $(\%), \mathrm{w}_{\mathrm{wf}}$ and $\mathrm{w}_{\mathrm{df}}$ were wet and dry weights of leaves, respectively, and $\left(\mathrm{w}_{\mathrm{wf}}-\mathrm{w}_{\mathrm{df}}\right)$ was the water mass in plant leaves.

Infiltration was obtained with a double ring infiltrometer by the usual method (Bhattacharya and Michael, 2003). Soil texture was determined using the hydrometer method (Gee and Bauder, 1986; In Klute, 1986). Bulk and dry densities were determined by the compaction method (Liu and Evett, 2000). Soil $\mathrm{pH}$ was measured with a $\mathrm{pH}$ meter having a glass electrode probe (Sim and Wolf, 1995).

Soil fertility tests were obtained from nutrients status (Wolf and Beagle, 1995). Available phosphorus was measured with either a supertonic 70 electrophotocalorimeter, or as described by Wolf and Beagle (1995). Total organic carbon (Nelson and Somers In Sparks, 1996) and total nitrogen (Bremmer, 1995) were determined with a combustion 1500 elemental analyser. Hydraulic conductivity: The permeability or hydraulic conductivity of the undisturbed soil samples, obtained with a soil sampler, was determined using a variable head permeameter (Liu and Evett, 2000; Suresh, 2008) and computed as:

$$
K=2.3 C \frac{a l}{A t} \log (h o / h e)
$$

Where $K$ was saturated hydraulic conductivity $(\mathrm{cm} / \mathrm{s})$, $\mathrm{C}$ was a correction factor at the observed temperature given as $\mathrm{C}=$ viscosity of water at observed temperature/viscosity of water at room temperature and all other variables were as defined above.

Tests of significance of mean square values between the sample soils A and B, B and C, and C and A were carried out using t- and F- ratio statistics, as well as ANOVA (Ofo, 1994; Kvanli et al., 2000).

\section{RESULTS AND DISCUSSION}

Moisture content: Mean moisture content varied from $11.6 \%$ on dry basis (db) in control plot to $7.04 \% \mathrm{db}$ and $8.57 \% \mathrm{db}$, respectively, in crude oil polluted soil and reclaimed soil samples. A significant moisture content reduction $(\mathrm{p}=0.01)$ in the polluted soil compared to unpolluted soil was observed. Thus, crude oil spillage reduced soil moisture availability or holding capacity, or increased moisture deficit in agricultural soils, damaging plant growth and yield (GIGR, 1999, Michael, 1978). Thus, the soil moisture content per unit weight of soil sample was less in crude oil-polluted wet soil (B) than in the unpolluted soil (A). Reclaimed soil (C) recovered the soil moisture storage capacity from $7.04 \%$ to $8.57 \%$.

Table 1: Root elongation (growth performance) in soil treatments

\begin{tabular}{ccccc}
\hline $\begin{array}{c}\text { Date } \\
(2007)\end{array}$ & Day & $\begin{array}{c}\text { Unpolluted } \\
(\mathrm{A}), \mathrm{cm}\end{array}$ & $\begin{array}{c}\text { Oil-polluted } \\
(\mathrm{B}), \mathrm{cm}\end{array}$ & $\begin{array}{c}\text { Reclaimed } \\
(\mathrm{C}), \mathrm{cm}\end{array}$ \\
\hline 25.09 & 1 & 6.40 & 6.35 & 6.38 \\
26.09 & 2 & 6.85 & 6.70 & 6.70 \\
27.09 & 3 & 7.30 & 6.85 & 6.90 \\
28.09 & 4 & 8.97 & 7.20 & 7.50 \\
29.09 & 5 & 10.35 & 7.45 & 8.45 \\
30.09 & 6 & & & \\
01.10 & 7 & & & \\
02.10 & 8 & 13.55 & 7.87 & 11.21 \\
03.10 & 9 & 17.30 & 7.88 & 12.22 \\
04.10 & 10 & 20.45 & 8.05 & 15.40 \\
05.10 & 11 & 21.55 & 8.10 & 17.05 \\
06.10 & 12 & 22.00 & 8.10 & 19.50 \\
Mean, $\overline{\boldsymbol{x}}$ & & 13.47 & 7.46 & 11.13 \\
& & & & \\
MSD, $\delta_{\mathrm{x}}$ & & \pm 6.35 & \pm 0.65 & \pm 4.77 \\
\hline
\end{tabular}

Note: mean difference between A and B significant @ P = 0.05; between A and C, not significant @ $\mathrm{P}=0.05$. Degradation in $\mathrm{B}=45 \%$; Recovery in $\mathrm{C}=82.65 \%$ of $\mathrm{A} . \overline{\mathrm{N}}=$ mean, $\delta \mathrm{x}=$ sample mean standard deviation.

Root elongation is a characteristic of a growing plant, and the results for the three treatments, are shown in Table 1. The impact on soil's physical structural parameters, like permeability for the three treatments (A, B and C) is shown in Table 2. Fertility test results
(Table 3) indicated that in all fertility components, the values for the polluted soil showed significant degradation $(\mathrm{P}=0.01)$ from those of unpolluted soil (Tables 3 and 4). 
The $\mathrm{pH}$ values were 4.5 for unpolluted, 5.8 for polluted and 4.8 for reclaimed soils. In contrast the change in $\mathrm{pH}$ from 4.5 in unpolluted loamy sand to 5.8 in crude oil polluted soil was a significant increase $(\mathrm{p}=0.05)$ and was attributed to the response of the soil to the oil pollution. Although Abii and
Nwosu (2009) failed to attribute such a slight change in acidity "entirely to the oil spill since the control was equally acidic", this change signified that spilling crude oil on agricultural soil tended to buffer the polluted soil towards neutral $\mathrm{pH}$ (Ellis et al., 1961).

Table 2: Hydraulic conductivity test results.

\begin{tabular}{|c|c|c|c|c|c|}
\hline No. of test & ho, cm & he, $\mathrm{cm}$ & $\mathrm{t}, \mathrm{s}$ & $1, \mathrm{~cm}$ & $\mathrm{~K}\left(\mathrm{x} 10^{-2} \mathrm{~cm} / \mathrm{s}\right)$ \\
\hline \multicolumn{6}{|c|}{ Unpolluted soil } \\
\hline 1 & 50 & 41 & 61 & 10 & 2.6 \\
\hline 2 & 50 & 35 & 20 & 10 & 2.4 \\
\hline 3 & 50 & 30 & 30 & 10 & 2.4 \\
\hline 4 & 50 & 26 & 40 & 10 & 2.2 \\
\hline 5 & 50 & 21 & 50 & 10 & 2.2 \\
\hline Mean, $\overline{\mathbf{x}}$ & & & & & 2.34 \\
\hline$\delta_{\mathrm{x}}$ & & & & & \pm 0.17 \\
\hline \multicolumn{6}{|l|}{ Polluted soil } \\
\hline 1 & 48 & 27.0 & 60 & 9.7 & 1.0 \\
\hline 2 & 44 & 24.2 & 60 & 9.7 & 1.1 \\
\hline 3 & 42 & 24.0 & 60 & 9.7 & 1.0 \\
\hline 4 & 40 & 20.6 & 60 & 9.7 & 1.3 \\
\hline 5 & 27 & 10.8 & 60 & 9.7 & 0.8 \\
\hline Mean, $\bar{x}$ & & & & & 1.14 \\
\hline$\delta_{\mathrm{x}}$ & & & & & \pm 0.15 \\
\hline \multicolumn{6}{|c|}{ Reclaimed soil } \\
\hline 1 & 50 & 14.0 & 61 & 11.3 & 2.3 \\
\hline 2 & 50 & 24.0 & 50 & 11.3 & 1.6 \\
\hline 3 & 50 & 28.0 & 40 & 11.3 & 1.6 \\
\hline 4 & 50 & 29.0 & 30 & 11.3 & 2.0 \\
\hline 5 & 50 & 34.0 & 24 & 11.3 & 2.2 . \\
\hline Mean, $\overline{\mathrm{x}}$ & & & & & 1.94 \\
\hline$\delta_{\mathrm{x}}$ & & & & & \pm 0.33 \\
\hline
\end{tabular}

Note: $h_{o}=$ level of water in permeameter manometer at $\mathrm{t}=0 ; \mathrm{cm} ; \mathrm{h}_{\mathrm{e}}=$ level of water in manometer at elapsed time $\mathrm{t}_{\mathrm{e}}$, $\mathrm{cm}$ $\mathrm{t}=$ elapsed time, $\mathrm{s} ; \mathrm{l}=$ length of soil cylinder, $\mathrm{cm} ; \mathrm{k}=$ hydraulic conductivity, $\mathrm{cm} / \mathrm{s}$; Significant mean difference between $\mathrm{A}$ and $\mathrm{B}$ at $\mathrm{p}=$ 0.01 ; mean difference between $\mathrm{C}$ and A not significant at $\mathrm{p}=0.05$. Degradation in $\mathrm{B}=51 \%$ of $\mathrm{A}$ and Recovery in $\mathrm{C}$ was $83 \%$ of original soil (A).

Table 3 shows the percentage moisture deficit in plants using leaf moisture loss. Mean evapotranspiration from the cowpea crop (Vigna unguiculata) was $7.7 \mathrm{ml}$ for $\mathrm{A}, 7.54 \mathrm{ml}$ for B and 7.8 $\mathrm{ml}$ for $\mathrm{C}$ (Table 4$)$; a reduction of $(2 \%)$ in polluted sample was observed. Using both t- and F-ratio statistics and ANOVA, the mean differences between hydraulic conductivity in $\mathrm{A}$ and $\mathrm{B}$, and $\mathrm{C}$ and $\mathrm{B}$ were significant at $\mathrm{p}=0.01$ level, but were not significant at $\mathrm{p}=0.01$ and 0.05 between $\mathrm{A}$ and $\mathrm{C}$, showing that crude oil hampered hydraulic conductivity of the loamy sand. The detergent/degreaser treatment, however, restored the hydraulic conductivity to average. Hydraulic conductivity of the soil samples (Table 2) was $0.025 \mathrm{~cm} / \mathrm{s}, 0.011 \mathrm{~cm} / \mathrm{s}$ and $0.019 \mathrm{~cm} / \mathrm{s}$ for A, B and C, respectively. Thus the polluted soil sample had comparatively less permeable soil than other samples, with a significant $(\mathrm{p}=0.01)$ mean difference (Table 2). Permeability in the reclaimed soil, on the other hand, was restored to original levels of permeability observed in the unpolluted soil.

Table 3: Mean concentrations of macronutrients in soil fertility analysis.

\begin{tabular}{cccc}
\hline Soil treatment & \multicolumn{3}{c}{ Mean nutrient concentration $\left(\times 10^{-3} \mathrm{~kg} / \mathrm{l}\right)$} \\
\cline { 2 - 4 } & Nitrogen & Total carbon & Available phosphorus \\
\hline Unpolluted, A & 0.242 & 0.15 & 0.9 \\
Polluted, B & 0.344 & 0.31 & 1.2 \\
Reclaimed, C & 0.250 & 0.22 & 0.6 \\
\hline
\end{tabular}

Note: Increases in soil B for N, C and P significant at $(\mathrm{p}=0.01)$ due to soil bacteria participation in biodegradation of oil resulting in increased carbon gas for carbon and increased atmospheric nitrogen fixing for nitrogen. Mean increase in fouled soil (B) was $42 \%, 106 \%$ and $33 \%$ of A for N, C and P, respectively. Recovery was $100 \%$ or more for $\mathrm{N}$ and C, and $67 \%$ for $\mathrm{P}$.

The bulk densities were $2.081 \mathrm{~g} / \mathrm{cm}^{3}$ and $1.873 \mathrm{~g} / \mathrm{cm}^{3}$ for $\mathrm{B}$ and $\mathrm{A}$, and $2.080 \mathrm{~g} / \mathrm{cm}^{3}$ and $1.860 \mathrm{~g} / \mathrm{cm}^{3}$ for their respective dry densities. Both results indicated significant mean differences, showing that the viscous crude oil settled into the pores to increase both the soil's wet weight and the liquid content. This 
in turn caused increases in both bulk and dry densities. Hence, crude oil spillage affected the physical properties of the soil as well.

Discussion on degradation: the reduction of soil moisture content to $7.04 \%$ in the oil-polluted soil was significantly very low for soil in a humid wetland during the rainy season (September/October) when the soil moisture is usually high $(>18 \%)$.

Evapotranspiration (Table 4) is the expiration of soil moisture in the soil-plant-water relationship. Plants absorb water available at the root zone and translocate it to the leaves for turgidity and metabolism. The amount of water transpired by the crop in its growth is used to calculate the unit weight of dry matter, which indicates healthy growth (Michael and Ojha, 2006). The significant reduction of moisture content (Table 4) and the reduced mean evapotranspiration of plants in polluted soil indicated very distressed root growth (see elongation in Table 1 ), hence resulting in inadequate water for plant nourishment and turgidity and subsequent wilting, significant high water deficit and low specific dry weight of leaves from the polluted soil (Table 4).

Table 4: Comparison of degradation by oil spill and restoration by degreaser/detergent

\begin{tabular}{|c|c|c|c|c|}
\hline Properties & $\begin{array}{c}\text { Control } \\
\text { A }\end{array}$ & $\begin{array}{c}\text { Degradation by oil } \\
\text { spill } \\
\text { B }\end{array}$ & $\begin{array}{c}\text { Restoration by } \\
\text { degreaser/deter } \\
\text { gent } \\
\text { C }\end{array}$ & Level of significance \\
\hline \multicolumn{5}{|l|}{ Soil } \\
\hline Mean infiltration rate, $\mathrm{cm} / \mathrm{hr}$ & 9.7 & 0.3 & 2.5 & $\mathrm{P}=0.01$ \\
\hline$\%$ change & - & 96.9 & 25.8 & \\
\hline Mean permeability x $10^{-2} \mathrm{~cm} / \mathrm{s}$ & 2.34 & 1.14 & 1.94 & $\mathrm{~A} \& \mathrm{~B}, \mathrm{P}=0.01$ \\
\hline$\%$ change & - & (51) & 83 & A \& $\mathrm{C}, \mathrm{ns} @ \mathrm{P}=0.05$ \\
\hline Mean moisture content & 11.7 & 71 & 94 & $\mathrm{~A} \& \mathrm{~B} P=0.01$ \\
\hline$\%$ change & - & $(39.3)$ & 80.3 & $\mathrm{~A} \& \mathrm{C}, \mathrm{ns} @ \mathrm{P}=0.05$ \\
\hline Mean bulk density & & 2.081 & 1.873 & \\
\hline Mean pH & 4.5 & 5.7 & 4.8 & $\mathrm{~A} \& \mathrm{~B}, \mathrm{P}=0.01$ \\
\hline$\%$ change & - & $26.7 *$ & 100 & A \& $\mathrm{C}, \mathrm{ns} @ \mathrm{P}=0.05$ \\
\hline Mean elongation $\mathrm{cm} /$ day & $7.4 \pm 0.64$ & & & \\
\hline$\%$ change & - & 45 & 82.65 & \\
\hline Turgidity & 13 & & & \\
\hline Mean (water mass) & $73.15 \pm 1.8$ & $62.30 \pm 5.60$ & $67.89 \pm 3.09$ & $\mathrm{P}=0.01$ \\
\hline$\%$ change & - & 92.39 & 92.82 & $\mathrm{~A} \& \mathrm{C}, \mathrm{ns} @ \mathrm{P}=0.05$ \\
\hline Mean water deficit & 3.6 & 3.15 & 3.34 & \\
\hline$\%$ change & - & 12.5 & 89.9 & \\
\hline Mean Nitrogen $x 10^{-3} \mathrm{~kg} / \mathrm{l}$ & 0.242 & 0.34 & 0.25 & $\mathrm{P}=0.01$ \\
\hline$\%$ change & - & $42 *$ & 100 & $\mathrm{~A} \& \mathrm{C}, \mathrm{ns} @ \mathrm{P}=0.01$ \\
\hline Mean phosphorus x $10^{-3} \mathrm{~kg} / \mathrm{l}$ & 0.98 & 1.2 & 0.62 & $\mathrm{P}=0.01$ \\
\hline$\%$ change & - & $33 *$ & 67 & $\mathrm{~A} \& \mathrm{C}, \mathrm{ns} @ \mathrm{P}=0.01$ \\
\hline Mean organic carbon $\times 10^{-3}$ & 0.15 & 0.31 & 0.22 & $\mathrm{P}=0.01$ \\
\hline $\mathrm{kg} / \mathrm{l}$ & - & $106^{*}$ & $>100$ & $\mathrm{~A} \& \mathrm{C}, \mathrm{ns} @ \mathrm{P}=0.01$ \\
\hline \multicolumn{5}{|l|}{$\%$ change } \\
\hline Evapotranspiration & 7.7 & 7.5 & 7.8 & \\
\hline
\end{tabular}

Note: Percentage recovery was generally greater than percentage degradation. ns $=$ mean difference not significant. *signifies increase in polluted

Root elongation: Roots elongate by extending themselves (the root hairs) in search of nutrient solutes for growth and for turgidity. When the roots are no longer able to absorb water from the soil, the crop loses its turgidity and wilts, or it may even die if the water in the soil is not replenished. The degradation reduced root elongation to $7.46 \mathrm{~cm}$, against $13.47 \mathrm{~cm}$ in the unpolluted soil, giving $45 \%$ degradation of growth in polluted soil, which growth reduction varied from $0.5 \mathrm{~cm} /$ day in the first five days to a constant rate of elongation of $1.1 \mathrm{~cm} /$ day in the next ten days, whereas in unpolluted soil, the rates varied from $1 \mathrm{~cm} /$ day to $3 \mathrm{~cm} /$ day in the first five and the next ten days, respectively. The wider range of dispersion from the mean (standard deviation $\delta_{\mathrm{x}}= \pm 6.35 \mathrm{~cm}$ ) for the control soil (Table 1) indicated a faster root elongation or growth than in the polluted soil (with a standard deviation $\delta_{\mathrm{x}}= \pm 0.65$ $\mathrm{cm})$. The latter insignificant standard deviation indicated a very slow or constrained root elongation, suggesting that soil B was too harsh, infertile and less permeable. The root elongation profile regressed against time (days), gave mathematical functions as follows: For polluted soil, an inverted exponential profile was obtained as:

$$
\begin{array}{ll}
Y_{t}=10.12\left(1-e^{-t}\right) & 3 \\
\text { or } Y_{\theta}=3.84 \ln t & 4
\end{array}
$$

where $\mathrm{Y}_{\mathrm{e}}$ is the root elongation and $\mathrm{t}$ is the number of days after emergence.

For the unpolluted soil, a third degree curve was modelled with a slope line given as: 


$$
\mathrm{Y}_{\mathrm{e}}=2.0431 \mathrm{t}+2.23, @ \mathrm{R}^{2}=0.945
$$

The difference between elongation in $\mathrm{A}$ and $\mathrm{B}$ as well as in $\mathrm{B}$ and $\mathrm{C}$ was found to be significant at $\mathrm{p}=0.01$, with the crude oil pollution depressing total root elongation of the same plant by $90 \%$. This reduction could be a disaster to food production and sustainability in areas where crude oil spills into agricultural land without quick reclamation.

Soil fertility (Table 4), in terms of soil nitrogen content, available phosphorus and total carbon showed apparent and significant increases (Tables 3 and 4) These increases confirmed the relationship between soil $\mathrm{pH}$ and soil nitrogen that the increase in $\mathrm{pH}$ with the oil spill contributed to the higher nitrogen value recorded in the crude oil contaminated soil (Foth, 1978). The observed increase in available phosphorus also confirmed earlier reports (Toogood et al., 1977). While organic carbon content in fouled soil also increased by $51 \%$ of the original soil level (Table 4) as adverse consequences of increased carbon dioxide in the fouled soil. These conditions are known to affect crop yield (Odjuvwuederhie et al., 2006).

Hydraulic conductivity or permeability: The reduction of soil permeability by up to $51 \%$ in crude oil polluted plots $(0.006 \mathrm{~cm} / \mathrm{s})$ from the unpolluted plot was a significant difference $(p=0.01, p \geq 0.05$, Table 2). Because soil permeability measures the ability of soil to transmit water in the porous media, the $81 \%$ reduction of soil permeability by crude oil pollution (Table 4) poses a serious disadvantage to agriculture. Soil cohesion could be reduced further and dislodged aggregate structure dispersed into the lower soil horizon, which would increase the obstruction of water movement below the root zone if more oil is spilled onto already contaminated land (Chinda and Braide, 2000).

The decrease of infiltration rate from $9.7 \mathrm{~cm} / \mathrm{hr}$ in the normal soil to a very low rate of $0.3 \mathrm{~cm} / \mathrm{hr}$ in the fouled soil, confirms the blocking of top-soil pores in the loamy sand of the coastal plain wetland. Thus, crude oil degraded water movement in the soil both at the level of the top-soil and below the crop root zone. Reclamation: The effect of applying the ameliorant (degreaser with detergent) on the crude oil fouledplot $(\mathrm{C})$ created a remarkable difference in properties from those of the fouled soil (B) (Tables 1, 2, 3 and 4). In contrast to previous soil degradation, hydraulic conductivity and infiltration rate in the reclaimed soil (Tables 2,4) were significantly higher than in the fouled soil $(\mathrm{p}=0.01)$, but without significant differences against the original soil (@ p = 0.01), indicating that the degreaser/detergent emulsion successfully recovered $82.9 \%$ of the beneficial properties of the original soil.

Root elongation: The plant growth factor recovered significantly in the reclaimed soil. (at $\mathrm{p}=0.01$ and $0.05)$ with the difference between the reclaimed and the original soil not significant; however, showing that root elongation recovered significantly in the reclaimed soil by $82.7 \%$ of the original soil (Table 1). The water deficit in plants (Table 4) showed a slightly different pattern, with its mean difference between the reclaimed and original soils being significant at the $\mathrm{p}=0.01$ level, but not at $\mathrm{p}=0.05$, and suggesting that with the $93 \%$ recovery, reclamation had unblocked soil pores, quickly enabling the plant roots to absorb adequate moisture from the soil and conduct it upward through the xylem and phloem for turgidity, balance and transpiration and growth recovery in plants. In terms of soil fertility (Table 3), total nitrogen, had a significant recovery $(\mathrm{p}=0.05)$; total carbon also exhibited significant recovery $(\mathrm{p}=0.01)$; while total phosphorus recovered remarkably (at 0.01 ) to 0.63 $\mathrm{mg} / \mathrm{l}$ in reclaimed soil compared to $0.9 \mathrm{mg} / \mathrm{l}$ in control soil. Soil $\mathrm{pH}$ recovered significantly $(\mathrm{p}=$ 0.01 ) to 4.8 in reclaimed soil compared to 4.5 in control soil.

Conclusion: A $3 \times 3$ block experiment was carried out on crude oil-polluted, reclaimed and unpolluted loamy sand planted with cowpeas (Vigna unguiculata). The effects of the crude oil spill on agricultural soil were tested, as well as the level of recovery of soil properties and crop growth by the remediating effect of the combined degreaser/detergent emulsion on the fouled soil. Engineering and physical properties of the soil, such as moisture content, permeability/hydraulic conductivity and infiltration rate, recorded significant $(p=0.01)$ degradation of $46-67 \%$ in the crude oil polluted soil compared to the original soil. The reclamation process recovered $83-93 \%$ quality in these soil properties. Root elongation and leaf water deficit, both crop growth indicators, recorded about $90 \%$ or more growth reduction in polluted soil. However, soil fertility elements - nitrogen, total carbon, available phosphorus and $\mathrm{pH}$, had $33-103 \%$ increases because of the bacterial biodegradation of oil in the anaerobic environment of the oil-blocked soil pores. This biodegradation also increased carbon gas (in the case of carbon) and atmospheric nitrogen fixing (for the observed nitrogen increase), while $\mathrm{pH}$ recorded a $26 \%$ increase. After reclamation, recovery was complete for nitrogen and carbon, and it was $67 \%$ for phosphorus. The use of chemical degreaser/detergent emulsions on the polluted agricultural soil effectively reclaimed the soil to $67-$ $100 \%$ of its original properties quality and disposed it 
to productive and profitable agricultural production after 21 days. The oil molecule bonds that contributed to the blocking of soil micro- and macropores were broken by the degreaser/detergent emulsion, thereby opening the media channel for water transfer, soil aeration and ionic exchange, as well as restoring evapotranspiration. Based on these results, the use of degreaser/detergent for agricultural soil reclamation after oil contamination is recommended for its biodegradable effect on the oil molecules. Also recommended are increased public awareness of the prospective environmental plight in oil operations and pre-emptive remedies amongst the oil industries, as well as more research projects and funding of reclamation of polluted agricultural soils.

\section{REFERENCES}

Abii, T A; Nwosu, P C (2009). The Effect of OilSpillage on the Soil of Eleme in Rivers State of the Niger Delta Area of Nigeria. Res J Environ Sci 3(3):316 - 320.

Aghalino, S O (2000). Petroleum Exploration and the Agitation for Compensation by Oil Mineral Producing Communities in Nigeria. J. Environ. Policy Issues, Vol. 1:11

Amadi, A; Abbey, S A; Nma, A (1996). Chronic Effect of Oil Spill on Soil Properties and Microflora of a Rainforest Ecosystem in Nigeria. Water, Air and Soil Pollution 86: $1-11$.

Anoliefo, G O; Nwosu D F (1994). Effects of Spent Lubricating Oil on the Growth of Capsicum annum. L and Lyeopersicun esculentum Miller. Environ. Pollut. 88:361 - 384 .

Atubi, A O; Onokala, P C (2006). The SocioEconomic Effects of Oil Spillage on Agriculture in the Niger Delta. J. Environ. Stud. 2:50 - 56.

Ayotamuno, M J; Kogbara R B (2005). Bioremediation of a Crude-Oil Polluted Agricultural-Soil at Port Harcourt, Nigeria, using different levels of nutrient application. Proc. NIAE, Vol 27, 2005. pp 352 - 360.

Bahttacharya, A K; Michael, A M (2003). Land Drainage Principle, Methods and Application. Lonark Publishers Pvt Ltd. Delhi 110092. pp 82 $-87$.

Bremmer, J M (1996). Nitrogen - Total. In D. L. Sparks (ed). Methods of Soil Analysis, Part 3. Chemical Methods. Soil Science Society of America Book Series Number 5. American Society of Agronomy, Madison WI. pp 1085 1121.
Brian, K (1977). Soil Processes. 1st Edition. Allen George Unwin. London.

Chinda; Braide, S A (2000). The Impact of Oil Spills on the Ecology and Economy of Niger Delta. Proceedings of the Workshop on Sustainable Remediation Development Technology, Held at the Institute of Pollution Studies, Rivers State University of Science and Technology, Port Harcourt, pp $1-11$.

CIGR (1999). Handbook of Agricultural Engineering, Vol. 1, Land and Water Engineering (Van Lier, H. N. and L. S. Pereira, Editors) pp $113-153$.

Daniel-Kalio, L A; Braide, S A (2004). The Effect of Oil Spill on a Cultivated Wetland Area of the Niger Delta. J. Nig. Environ. Soc. 2(2); 153 158. www.bioline.org.br/request?ja06034

Daniel-Kalio, L A; Pepple, S F (2006). Effect of Bonny Light Crude Oil Pollution of Soil on the Growth of DayFlower (Commelina benghalensis L.) in Niger Delta, Nigeria. J. Appl. Sci. Environ. Mgt. June. 10(2), $111-114$.

http:// www.bioline.org.br/request?ja06034

De Wrachien, D; Chisci, G (1999). Land Reclamation and Conservation (Soil Reclamation). In CIGR, Handbook of Agricultural Engineering Vol. 1. pp $113-135$.

Ellis, R; Adams, R S (1961). Contamination of Soil by Petroleum Hydrocarbons, Advanced Agronomy, Vol. 13, 197 - 216.

Foth, H D (1978). Fundamentals of Soil Science, Environmental Pollution. Vol. 11. pp. $201-222$.

Gee, G W; Bauder, J W (1986). Particle Size Analysis. In A. Klute (ed). Methods of Soil Analysis Part 1. Physical and Mineralogical Monograph N9 ( $2^{\text {nd }}$ edition). Amer. Soc. Agron, Madison, WI. pp $383-411$.

Henry, J G; Heinke, G W (2005). Environmental Science and Engineering, $2^{\text {nd }}$ ed. Prentice Hall, India, New Delhi 110001, 64 - 84.

Kvanli, A H; Guynes, C S (2000). Introduction to Business Statistics $5^{\text {th }}$ edn, South-Western College Publishing, USA.

Liu, C; Evett, J B (2000). Soil Properties: Testing, Measurement and Evaluation, $4^{\text {th }}$ Edn. Prentice Hall, New Jersey. 
Michael, A M (1978). Irrigation: Theory and Practice. Vikas Publishing House, New Delhi, 801p.

Michael, A M; Ojha, T P (2006). Principles of Agricultural Engineering Vol. II. $5^{\text {th }}$, Edition, Jain Brothers, New Delhi, pp. 331 - 390.

Nelson, O W; Sommers, L E (1996). Total Carbon, Organic Carbon Organic Matter. In O. L. Sparks (ed). Methods of Soil Analysis Part 3, Chemical Methods. Soil Science Society of America Book Series Number 5. American Society of Agronomy, Madison WIE, pp 961 - 1010.

Ngobiri, C N; Ayuk, A A; Awunuso, I I (2007). Differential Degradation of Hydrocarbon Fractions During Bioremediation of Crude Oil Polluted Sites in Niger Delta. J. Chem.. Soc. Nigeria. 32:151 - 159 .

Odjuvwuederhie, I; Donglason Omoborand, G; Felicia Adun N (2006). The Effect of Oil Spillage on Crop Yield and Farm Income in Delta State of Nigeria. J. Central Eur. Agric; 7(1):41 - 48. Available at www.agr.hr/jcea/issues/jcea7-1/pdf/jcea71-6.pdf. Accessed on 09.09.2010.

Odugwu, E C; Onianwa, A T (1987). Environmental Impact Assessment - A Case Study of Utorogu
198416 Delivery Line Spillage. Proc. Int Sem on Pet Ind of the Nig. Environ. pp $228-301$.

Ofo, H J E (1994). Research Methods and Statistics in Education and Social Sciences, Joja Edu. Research and Publishers Ltd, Ikeja, Lagos.

Sims, T; Wolf, A (eds). (1995). Recommended Soil Testing Procedure. Northeastern Regional Bulletin 493 Agricultural Experimental Station, University of Delaware, Newark, DE.

Suresh, R (2008). Land and Water Management Principles. Standard Publishers Distributors, Delhi - 110006. pp. $243-246$.

Toogood, J A; Rowell, M P; Ngborg, M (1977). Reclamation Experiment in the Reclamation of Agricultural Soils after Spills. Part 1: Research (J. A. Toogood, ed), A. I. P. Publishers, pp 34 64.

Whitten, K W; Gailey, K D; Davis, R E (1985). General Chemistry $3^{\text {rd }}$ Edn. Sounteys Holder Sunburst Series.

Wolf, A; Beagle, D B (1995). Recommended Soil Tests for Macronutrients Phosphorus, Potassium, Calcium and Magnesium. In Thomas Sims and A. Wolf (eds). Recommended Soil Testing Procedures for Northeastern United States. Northeast Regional Bulletin 493 Agricultural Experimental Station, University of Delaware Newark. DE, pp $25-34$. 